\title{
Shared decision-making: the perspectives of young adults with type I diabetes mellitus
}

\author{
This article was published in the following Dove Press journal: \\ Patient Preference and Adherence \\ 2 April 2014 \\ Number of times this article has been viewed
}

\author{
Janice Wiley' \\ Mary Westbrook' \\ Jerry R Greenfield ${ }^{2,3}$ \\ Richard O Day ${ }^{4}$ \\ Jeffrey Braithwaite' \\ 'Centre for Clinical Governance \\ Research in Health, Australian \\ Institute of Health Innovation, \\ University of New South Wales, \\ ${ }^{2}$ Diabetes and Obesity Program, \\ Garvan Institute of Medical Research, \\ ${ }^{3}$ Department of Endocrinology, St \\ Vincent's Hospital, University of \\ New South Wales, Sydney, NSW, \\ Australia; ${ }^{4}$ Department of Clinical \\ Pharmacology, St Vincent's Hospital, \\ University of New South Wales, \\ Sydney, NSW, Australia
}

Background: Shared decision-making (SDM) is at the core of patient-centered care. We examined whether young adults with type 1 diabetes perceived the clinician groups they consulted as practicing SDM.

Methods: In a web-based survey, 150 Australians aged 18-35 years and with type 1 diabetes rated seven aspects of SDM in their interactions with endocrinologists, diabetes educators, dieticians, and general practitioners. Additionally, 33 participants in seven focus groups discussed these aspects of SDM.

Results: Of the 150 respondents, $90 \%$ consulted endocrinologists, $60 \%$ diabetes educators, $33 \%$ dieticians, and $37 \%$ general practitioners. The majority of participants rated all professions as oriented toward all aspects of SDM, but there were professional differences. These ranged from $94.4 \%$ to $82.2 \%$ for "My clinician enquires about how I manage my diabetes"; $93.4 \%$ to $82.2 \%$ for "My clinician listens to my opinion about my diabetes management"; $89.9 \%$ to $74.1 \%$ for "My clinician is supportive of my diabetes management"; $93.2 \%$ to $66.1 \%$ for "My clinician suggests ways in which I can improve my self-management"; $96.6 \%$ to $85.7 \%$ for "The advice of my clinician can be understood"; $98.9 \%$ to $82.2 \%$ for "The advice of my clinician can be trusted"; and $86.5 \%$ to $67.9 \%$ for "The advice of my clinician is consistent with other members of the diabetes team". Diabetes educators received the highest ratings on all aspects of SDM. The mean weighted average of agreement to SDM for all consultations was $84.3 \%$. Focus group participants reported actively seeking clinicians who practiced SDM. A lack of SDM was frequently cited as a reason for discontinuing consultation. The dominant three themes in focus group discussions were whether clinicians acknowledged patients' expertise, encouraged patients' autonomy, and provided advice that patients could utilize to improve self-management.

Conclusion: The majority of clinicians engaged in SDM. Young adults with type 1 diabetes prefer such clinicians. They may fail to take up recommended health services when clinicians do not practice this component of patient-centered care. Such findings have implications for patient safety, improved health outcomes, and enhanced health service delivery.

Keywords: shared decision-making, patient perspective, patient-centered care, patient autonomy, type 1 diabetes, young adults, health service delivery, glycemic control

\section{Background}

Shared decision-making (SDM) is a practice whose time has come. SDM is a consultation style that involves both the patient and the clinician sharing information and management options to reach agreement on treatment implementation. ${ }^{1-3}$ It is a core component of patient-centered care. ${ }^{4}$ Whilst patient-centered care has had various definitions, ${ }^{5}$ other elements considered essential include clinician consideration of 
patient needs and preferences, ${ }^{6-8}$ health literacy skills, ${ }^{6-8}$ and accessibility to health services. ${ }^{7,8}$

Across the USA, the UK, Europe, Canada, and Australia, there is an impetus to move to more patient-centered systems of care..$^{2,3,5,9-14}$ Efforts to improve health service quality and safety, changing social attitudes, and an ethical imperative have been amongst the driving forces..$^{2,3,5,9,15}$ In respect of diabetes health service provision, patient-centered systems of care have been associated with improved glycemic control, ${ }^{16,17}$ greater patient satisfaction, ${ }^{17,18}$ higher levels of patient well-being, ${ }^{18,19}$ increased patient engagement, ${ }^{17-19}$ and more provider satisfaction. ${ }^{19}$

SDM acknowledges patient expertise and preferences by incorporating the patient as an active partner alongside the clinician in defining appropriate medical management. ${ }^{2,3}$ This emerging ideology has particular relevance in chronic disease management where the need for collaborative, integrated, and accessible care aligns with patient engagement in forms of self-management. ${ }^{20}$ In keeping with societal shifts in consumer sovereignty and greater levels of individualization, the role of SDM might be better understood by a consideration of self-determination theory, which suggests that clinician consultation attitudes that inhibit patient autonomy may lead to poorer health outcomes. ${ }^{21}$ Self-determination theory has been shown to be applicable to an understanding of improved glycemic control in diabetes management. ${ }^{22}$ SDM might acknowledge the practical reality of equalizing rights and power in the health provider-patient relationship as well as empowerment of the patient in taking increasing responsibility for his or her own care.

Yet it appears that SDM may be an academic fiction rather than common practice. Active engagement of the patient in decision-making regarding management is often neglected ${ }^{2,3,23,24}$ despite evidence that the majority of patients want greater involvement in determining their own care. ${ }^{24-28}$ Such studies emphasize a growing disjunction between policy requirements signaling a more collaborative orientation to care decisions and traditional practice.

As the quintessential self-managed disease, type 1 diabetes mellitus is at the cutting edge of this ideological evolution. Type 1 diabetes is an autoimmune disease that necessitates lifelong insulin replacement therapy. Effective self-management of type 1 diabetes requires an ability to formulate algorithms for insulin replacement dependent upon a complex array of interactive physiological parameters. ${ }^{29-35}$ In circumstances where the patient must rely to some extent on the expertise of their own daily therapeutic decision-making, adherence to a didactically prescribed clinician management plan may leave the patient in an untenable position. Incorporation of SDM into a consultation results in a two-way flow of experiential knowledge between the clinician and the patient, and allows for identification of the barriers that may impede achievable treatment goals. SDM can be an effective method for both the patient and the health care provider to reach consensus on implementation of an effective treatment regimen. ${ }^{36}$

Young adults with type 1 diabetes are of particular interest because they have high attrition rates from health services ${ }^{37,38}$ and suffer worse health outcomes. ${ }^{37}$ Yet the use of patients' perspectives as a driver for quality and safety improvements in health services is underdeveloped. ${ }^{39}$ This study seeks to address the research gap. We set out to explore the experience of SDM from the perspective of young adults with type 1 diabetes. We wanted to assess whether and to what extent factors fundamental to the process of SDM in multidisciplinary clinician care of type 1 diabetes are becoming manifest.

\section{Materials and methods Participants}

The study population was a sample of Australian adults aged 18-35 years with type 1 diabetes. Participants were recruited from Australian diabetes consumer support organizations via advertisements on websites, e-newsletters, Facebook, and print journals in 2011. To obtain qualitative data, focus groups were conducted in all state capital cities except Hobart, with some participants travelling from regional areas. The University of New South Wales granted ethics approval (HREC 10395). All participants provided their individual informed consent. Age-limited inclusion criteria for the study were established because of the high attrition rates and poor health outcomes known to occur in this age group..$^{37,38}$ Exclusion criteria were people with type 1 diabetes outside of the set age limits, those with type 1 diabetes not living in Australia, and carers of those with type 1 diabetes.

\section{Survey}

The quantitative component of the study consisted of a webbased, self-reported, cross-sectional survey of methods of diabetes self-management. The survey was available online from February to May 2011. A paper version of the survey was available but was not utilized by any respondent. The survey consisted of 96 questions that covered a comprehensive assessment of factors relevant to type 1 diabetes self-management although not all questions were relevant to every respondent. (For example, questions related to use of continuous insulin infusion devices were not relevant to respondents who used multiple daily injections.) The survey was developed in 2010 
by the authors following a systematic literature review on type 1 diabetes self-management, because no available type 1 diabetes self-management assessment tools gave consideration to the role of new technologies. Following assessment of respondent demographic characteristics, the survey addressed questions related to modes, frequency, and evaluation of insulin delivery systems and blood glucose monitoring systems. The survey also explored respondents' record-keeping, dietary management, insulin adjustment, and blood glucose target levels (including in the event of exercise, sick days, alcohol consumption), and identification and evaluation of health services and diabetes education accessed. The survey was piloted on a sample of four young adults with type 1 diabetes and ten health services workers and researchers. Recommended improvements were incorporated into the final version. A set of seven questions fundamental to SDM was included. These questions were modified from results of studies of SDM by the Commonwealth Fund, a private US foundation that aims to promote high-performing health care systems. ${ }^{40}$

Participants were asked to rate their interactions with each of the four types of clinicians in the multidisciplinary diabetes team that they consulted. The clinicians included were an endocrinologist, a diabetes educator (a specialist nurse with an accredited post-graduate certificate or diploma in diabetes education), a dietitian, and a general practitioner. Seven-point Likert scales with endpoints "agree" and "disagree" (mid-point "neutral") were used for each of seven questions related to SDM. The questions rated were: my (clinician type specified) enquires about how I manage my diabetes; my (clinician) listens to my opinion about my diabetes management; my (clinician) is supportive of my diabetes management; my (clinician) suggests ways in which I can improve my self-management; the advice of my (clinician) can be understood; the advice of my (clinician) can be trusted; and the advice of my (clinician) is consistent with other members of the diabetes team.

Such questions sought participants' perceptions of the two-way flow of information required for SDM to occur. For example, the question regarding the clinician's enquiry about self-management examined whether the clinician had requested information regarding self-management skills from the patient. The question regarding the clinician listening to the patient asked whether from the patient's perspective the clinician had taken account of that information. These facets of SDM stand in contrast to the questions regarding the provision of advice by the clinician. These questions sought to ascertain not only whether the clinician provided information but also whether it was in a format that could be utilized by the patient. The provision of inconsistent information or information that the patient did not trust might impact on patients' perceptions of the two-way flow of information.

No specific time frame to limit when the consultation experience occurred was allocated in the survey. Although it is recommended care, questions related to consultation with a psychologist or social worker were not included due to the complexities of a therapeutic alliance.

\section{Focus groups}

To expand on the results of the survey, participants were invited by email to attend focus groups. Focus groups were conducted from May to August 2011. The focus group method was chosen because focus groups can stimulate participants to explore their own perceptions in ways that may not come to light in personal interviews. ${ }^{41}$ The focus groups had a semistructured format. Each facet of SDM, as detailed in the survey, was raised by way of an open-ended question asking the group to tell of their experiences in relation to that issue. The focus group discussion continued until content saturation was achieved. Interviews were electronically recorded and transcribed verbatim. The interviewer (JW) wrote notes after each meeting, reflecting on the principal matters discussed and recording the perceived feelings, emotions, and personal interactions of the participants.

\section{Data processing and analysis}

Only completed responses were incorporated into the data analysis. Quantitative analysis was undertaken using Statistical Package for the Social Sciences version 20 software (IBM Corporation, Armonk, NY USA). In reporting the survey results for the SDM questions, the three levels of agreement and disagreement were respectively combined whilst the neutral responses remained constant. A mean weighted average agreement for SDM across all clinicians was calculated. Sections of the survey also provided for free text responses. These responses were incorporated into the qualitative data generated by the focus groups.

The qualitative data were analyzed with the aid of the QRS NVivo 9 (QSR International, Doncaster, VIC, Australia) data analysis program for thematic content using a constant comparative method for emerging themes. ${ }^{42}$ Two health services researchers, a registered nurse (JL) and a registered medical practitioner (JW) with clinical experience in diabetes care, independently analyzed these results. Data were coded using stepwise thematic analysis. Recurring themes and subthemes were clustered and then condensed into overarching themes. Emerging qualitative themes and subthemes were compared 
with quantitative results for consistency. A third health services researcher (MW) analyzed the quantitative and qualitative data to check for thematic consistency and interpretative analysis. Exemplar quotes are presented using participants' identifier codes, sex, age, and duration of diabetes.

\section{Results}

\section{Survey}

Of 167 commenced survey responses, 150 respondents completed all survey questions. This represented a survey response rate of $89.8 \%$.

\section{Demographic and clinical characteristics of survey participants}

As shown in Table $1,80 \%$ of the survey participants were female, $80 \%$ came from the eastern states (reflecting Australian population demographics), 68\% were living in major cities,

Table I Demographic characteristics of I 50 survey participants

\begin{tabular}{ll}
\hline Age, years & \\
I8-24 & $46(30.67 \%)$ \\
$25-29$ & $52(34.67 \%)$ \\
$30-35$ & $52(34.67 \%)$ \\
Sex & \\
Male & $30(20.0 \%)$ \\
Female & $120(80.0 \%)$ \\
Australian state or territory & \\
Queensland & $29(19.33 \%)$ \\
New South Wales & $43(28.67 \%)$ \\
Victoria & $41(27.33 \%)$ \\
Tasmania & $8(5.33 \%)$ \\
South Australia & $10(6.67 \%)$ \\
Western Australia & $14(9.33 \%)$ \\
Australian Capital Territory & $4(2.67 \%)$ \\
Northern Territory & $1(0.67 \%)$ \\
Residential area & \\
Major city & $102(68.0 \%)$ \\
Regional city & $31(20.67 \%)$ \\
Rural area & $14(9.33 \%)$ \\
Remote area & $3(2.0 \%)$ \\
Level of education & \\
Secondary & $32(21.33 \%)$ \\
Tertiary & $79(52.67 \%)$ \\
Post-graduate & $39(26.0 \%)$ \\
Occupation & \\
Full time student & $17(11.33 \%)$ \\
Primarily part time student & $3(2.0 \%)$ \\
Working full time & $96(64.0 \%)$ \\
Curimarily working part time & $15(10.0 \%)$ \\
Other & $8(5.33 \%)$ \\
Private health insurance & $11(7.33 \%)$ \\
Yes & \\
No & $126(84.0 \%)$ \\
\hline & $24(16.0 \%)$ \\
\hline
\end{tabular}

$79 \%$ had attained a tertiary education level, 64\% were working full time, and $84 \%$ had private health insurance.

The clinical diabetes characteristics were self-reported. As shown in Table 2, 34\% reported that their last hemoglobin $\mathrm{A}_{1 \mathrm{c}}\left(\mathrm{HbA}_{1 \mathrm{c}}\right)$ was less than $7.0 \%$ (53 mmol $\left./ \mathrm{mol}\right), 45 \%$ reported that their body mass index was in the normal range, $25.3 \%$ had a duration of diabetes of less than 5 years, and $39.3 \%$ had a duration of diabetes of greater than 15 years.

\section{Consultation characteristics of survey participants}

Of the 150 respondents, the numbers of participants who currently consulted with each type of clinician on the recommended diabetes care team were as follows: endocrinologists, 135 (90\%); diabetes educators, 89 (60\%); dieticians, 50 (33\%); and general practitioners, 56 (37\%). Two percent of our respondents did not currently consult with any clinician. On average, respondents consulted 2.3 types of clinicians.

\section{Survey results}

Overall, the participants affirmed that the majority of clinicians in the four professions demonstrated SDM on all seven aspects of decision-making that were investigated. Totaled participant affirmative, negative, and neutral responses respectively to questions related to SDM are shown in Table 3. Comparing the ratings given to individual facets

Table 2 Clinical characteristics of 150 survey participants

\section{Duration of diabetes, years}

$<5$

$5-10$

$38(25.3 \%)$

$11-15$

$30(20.0 \%)$

$16-20$

$23(15.3 \%)$

$>20$

$26(17.3 \%)$

$33(22.0 \%)$

HbA

Don't know $6(4.0 \%)$

$<7 \%$

$7.1 \%-7.5 \%$

$5 \mathrm{I}(34.0 \%)$

$7.6 \%-8.0 \%$

$30(20.0 \%)$

$18(12.0 \%)$

$8.1 \%-8.5 \% \quad 21(14.0 \%)$

$8.6 \%-9.0 \% \quad 9(6.0 \%)$

$>9.0 \%$

$15(10.0 \%)$

$\mathrm{HbA}_{\mathrm{Ic}}$ performed in the last 6 months

Yes

$135(90.0 \%)$

No

Body mass index $\left(\mathrm{kg} / \mathrm{m}^{2}\right)$

Don't know

$15(10.0 \%)$

$<19$

$34(22.7 \%)$

$5(3.3 \%)$

19 to $<25 \quad 67(44.7 \%)$

$25-30 \quad 33(22.0 \%)$

$>30$

II (7.3\%) 
Table 3 Evaluation of clinician engagement in shared decision-making by participants currently consulting clinician groups

\begin{tabular}{|c|c|c|c|c|c|}
\hline \multirow{2}{*}{$\begin{array}{l}\text { Responses to } \\
\text { survey items }\end{array}$} & \multicolumn{5}{|l|}{ Clinician groups } \\
\hline & $\begin{array}{l}\text { Endocrinologists } \\
n=135\end{array}$ & $\begin{array}{l}\text { Diabetes educators } \\
\mathrm{n}=\mathbf{8 9}\end{array}$ & $\begin{array}{l}\text { Dieticians } \\
n=50\end{array}$ & $\begin{array}{l}\text { General practitioners } \\
n=56\end{array}$ & $\begin{array}{l}\text { Group average } \\
n=4\end{array}$ \\
\hline \multicolumn{6}{|c|}{ I. My (clinician) enquires about how I manage my diabetes } \\
\hline Agree & $82.2 \%$ & $94.4 \%$ & $84.0 \%$ & $87.5 \%$ & $87.0 \%$ \\
\hline Neutral & $4.5 \%$ & $3.4 \%$ & $2.0 \%$ & $8.9 \%$ & $4.7 \%$ \\
\hline Disagree & $13.3 \%$ & $2.2 \%$ & $14.0 \%$ & $3.6 \%$ & $8.3 \%$ \\
\hline \multicolumn{6}{|c|}{ 2. My (clinician) listens to my opinion about my diabetes management } \\
\hline Agree & $76.3 \%$ & $93.3 \%$ & $80.0 \%$ & $82.2 \%$ & $82.9 \%$ \\
\hline Neutral & $8.1 \%$ & $2.2 \%$ & $10.0 \%$ & $8.9 \%$ & $7.3 \%$ \\
\hline Disagree & $15.6 \%$ & $4.5 \%$ & $10.0 \%$ & $8.9 \%$ & $9.7 \%$ \\
\hline \multicolumn{6}{|c|}{ 3. My (clinician) is supportive of my diabetes management } \\
\hline Agree & $74.1 \%$ & $89.9 \%$ & $80.0 \%$ & $85.7 \%$ & $82.4 \%$ \\
\hline Neutral & $9.6 \%$ & $4.5 \%$ & $8.0 \%$ & $7.2 \%$ & $7.3 \%$ \\
\hline Disagree & $16.3 \%$ & $5.6 \%$ & $12.0 \%$ & $7.1 \%$ & $10.3 \%$ \\
\hline \multicolumn{6}{|c|}{ 4. My (clinician) suggests ways in which I can improve my self-management } \\
\hline Agree & $80.7 \%$ & $93.2 \%$ & $90.0 \%$ & $66.1 \%$ & $82.5 \%$ \\
\hline Neutral & $6.7 \%$ & $3.4 \%$ & $2.0 \%$ & $10.6 \%$ & $5.7 \%$ \\
\hline Disagree & $12.6 \%$ & $3.4 \%$ & $8.0 \%$ & $23.3 \%$ & $11.8 \%$ \\
\hline \multicolumn{6}{|c|}{ 5. The advice of the (clinician) can be understood } \\
\hline Agree & $87.4 \%$ & $96.6 \%$ & $88.0 \%$ & $85.7 \%$ & $89.4 \%$ \\
\hline Neutral & $7.4 \%$ & $1.1 \%$ & $4.0 \%$ & $10.7 \%$ & $5.8 \%$ \\
\hline Disagree & $5.2 \%$ & $2.3 \%$ & $8.0 \%$ & $3.6 \%$ & $4.7 \%$ \\
\hline \multicolumn{6}{|c|}{ 6. The advice of the (clinician) can be trusted } \\
\hline Agree & $85.2 \%$ & $98.9 \%$ & $92.0 \%$ & $82.2 \%$ & $89.5 \%$ \\
\hline Neutral & $6.7 \%$ & 0 & $4.0 \%$ & $8.9 \%$ & $4.9 \%$ \\
\hline Disagree & $8.1 \%$ & $1.1 \%$ & $4.0 \%$ & $8.9 \%$ & $5.5 \%$ \\
\hline \multicolumn{6}{|c|}{ 7. The advice of the (clinician) is consistent with other members of the diabetes team } \\
\hline Agree & $75.6 \%$ & $86.5 \%$ & $78.0 \%$ & $67.9 \%$ & $77.0 \%$ \\
\hline Neutral & $17.0 \%$ & $7.9 \%$ & $14.0 \%$ & $21.4 \%$ & $15.1 \%$ \\
\hline Disagree & $7.4 \%$ & $5.6 \%$ & $8.0 \%$ & $10.7 \%$ & $7.9 \%$ \\
\hline \multicolumn{6}{|c|}{ Average response to survey items } \\
\hline Agree & $80.2 \%$ & $93.3 \%$ & $84.6 \%$ & $79.6 \%$ & $84.3 \%$ \\
\hline Neutral & $9.8 \%$ & $3.2 \%$ & $6.3 \%$ & $11.0 \%$ & $7.4 \%$ \\
\hline Disagree & $10.0 \%$ & $3.5 \%$ & $9.1 \%$ & $9.4 \%$ & $8.3 \%$ \\
\hline
\end{tabular}

of SDM, the highest average agreement was that the advice of clinicians could be trusted at $89.5 \%$; the advice could be understood at $89.4 \%$ and that clinicians enquired about how patients manage their diabetes at $87.0 \%$. The lowest agreement $(77.0 \%)$ was with the proposition that advice from multidisciplinary team clinicians was consistent.

An SDM estimate was calculated for each clinician group by averaging the percentages of participants who agreed with each of the seven questions regarding that group. For example, as shown in Table 3, an average of $80.2 \%$ agreed that their endocrinologists demonstrated the qualities the questions asked about, ranging from $74.1 \%$ who agreed that their endocrinologists were supportive of their diabetes management to $85.2 \%$ who thought their advice could be trusted. Comparing the proportions of patients reporting SDM across clinician groups, the group rated as demonstrating the most SDM was diabetes educators $(93.3 \%)$. Dieticians attracted the second highest average score at $84.6 \%$, followed by endocrinologists at $80.2 \%$ and general practitioners at $79.6 \%$. The mean weighted average of agreement to SDM for all consultations was $84.3 \%$.

\section{Focus groups}

Characteristics of focus group participants

These were a subset of the survey participants. Sixty-eight respondents expressed interest in attending the focus groups, but only 33 participants (27 females [81.8\%] and six males [18.1\%]) were available for the organized dates and venues. All participants came from major or regional cities. Their mean age was 25.1 (range 20-33) years. The mean duration of type 1 diabetes was 10.5 (range $0.5-25$ ) years.

\section{Focus group results}

Focus group results expanded on the survey findings. They acted to both reinforce the positive responses of those who 
continued to consult various clinician groups but also to give insights into the experiences of participants where there was a failure by clinicians to engage in SDM. Participants who had type 1 diabetes of longstanding duration reported that over the period of their illness there had been a notable change in clinicians' consultation style from a model representative of an attitude of "here is your regimen, you stick to it", to one that embraced such SDM attitudes:

It was a brutal experience. ... He (the endocrinologist) always made me feel like I was doing the wrong thing. ... It was a very intensive experience where it was; 'this is the way you do it!' ... Diabetes management at the time was not flexible because insulins weren't at that level but that meant that the way they treated it was here is your regimen, you stick to it. Any deviation from that was seen as something that needed to be corrected. ... But something has happened in diabetes care that has changed over the last ten years. ... I don't handle very well being told what to do. ... But now I am presented with options and when I say that bad things have happened she just basically takes it and goes $\mathrm{OK}$ so what is going to happen next time so that there is no disappointment. When I do things, which she thinks are a positive step, I get lots of affirmations. So it's amazing! (woman aged 32 years, with a type 1 diabetes mellitus duration of 25 years).

Three major themes emerged from the focus group data. These related to: whether clinicians engaged in behavior that acknowledged patients' expertise; whether clinicians engaged in behavior that was supportive and encouraged patients' autonomy; and whether clinicians provided advice that patients could utilize to improve their self-management skills. Table 4 shows the hierarchy of the themes and subthemes identified in thematic analysis.

\section{Clinicians' behavior when acknowledging patients' expertise}

Thematic analysis revealed two categories of factors impacting on clinician behavior to indicate that they acknowledged their patients' expertise (Table 5). These two factors related to the capacity of clinicians to enquire about their patients' self-management practices and to listen to their patients' opinion regarding their experience of self-management implementation.

\section{Whether the clinician enquired about self-management}

From a positive perspective, participants spoke of clinicians who treated the consultation as an open forum where patient expertise
Table 4 Thematic analysis of focus group results

\begin{tabular}{|c|c|c|}
\hline $\begin{array}{l}\text { Corresponding } \\
\text { table }\end{array}$ & Overarching theme & Subtheme \\
\hline 5 & $\begin{array}{l}\text { Clinicians' behavior to } \\
\text { acknowledge patients' } \\
\text { expertise }\end{array}$ & $\begin{array}{l}\text { Whether the clinician } \\
\text { enquired about self- } \\
\text { management } \\
\text { Whether the clinician } \\
\text { listened to the patient's } \\
\text { opinion about self- } \\
\text { management }\end{array}$ \\
\hline 6 & $\begin{array}{l}\text { Whether clinicians' } \\
\text { behavior was supportive } \\
\text { and encouraged patients' } \\
\text { autonomy }\end{array}$ & $\begin{array}{l}\text { Supportive clinician } \\
\text { behavior } \\
\text { Unsupportive clinician } \\
\text { behavior }\end{array}$ \\
\hline 7 & $\begin{array}{l}\text { Whether clinicians } \\
\text { provided advice that } \\
\text { patients could utilize } \\
\text { to improve self- } \\
\text { management }\end{array}$ & $\begin{array}{l}\text { Capacity of participant } \\
\text { to be able to trust the } \\
\text { clinician's advice } \\
\text { Consistency of the } \\
\text { advice provided across } \\
\text { the health care team } \\
\text { Whether the clinician } \\
\text { suggested new } \\
\text { technologies for self- } \\
\text { management }\end{array}$ \\
\hline
\end{tabular}

was sought, listened to, acknowledged, respected, and incorporated into the management regimen (Table 5, quotes 1 and 2). However, some participants perceived that there was a division of responsibility for SDM and that it was not the role of the endocrinologist to enquire about self-management. This division of clinician engagement in shared decision making was acceptable to some participants (Table 5, quotes 3 and 4). However, many participants expressed frustration that they had experienced negative interactions related to SDM across multidisciplinary clinician consultations. The reports of failure by some endocrinologists, in particular, to engage in a greater degree of SDM were consistent with the reported perceptions that clinicians were "time-poor", and "results-orientated" (Table 5, quotes 5 and 6). Such time constraints led to situations where clinicians failed to enquire about the participants' selfmanagement practices. Participants perceived that the failure of clinicians to enquire about self-management practices was associated with a lack of respect for the expertise of the patient and led to feelings of disempowerment (Table 5, quotes 7 and 8). Further, failure of the clinician to enquire about the participants' self-management was a reason cited for discontinuing consultation with that clinician (Table 5, quotes 9 and 10).

\section{Whether the clinician listened to the patient's opinion about self-management}

Participants emphasized the need for clinicians to listen to their patients' opinions about their self-management 
Table 5 Participant quotations as to whether clinicians' behavior acknowledged patient expertise

\begin{tabular}{|c|c|}
\hline Quotation number & Quotation \\
\hline \multicolumn{2}{|c|}{ Whether the clinician enquired about self-management } \\
\hline 1 & $\begin{array}{l}\text { "They (the diabetes educators) really do. They will actually ask me what l've done to try and treat it and when I say this is } \\
\text { what I think I will do they will handle that OK." (Female patient aged } 32 \text { years, TIDM duration } 25 \text { years) }\end{array}$ \\
\hline 2 & $\begin{array}{l}\text { "He (the endocrinologist) will listen to me and then he will say this is what I think you need to do to get your numbers down. } \\
\text { Then he will say to me; what are you doing to get your numbers down?" (Male patient aged } 25 \text { years, TIDM duration } 6 \text { years) }\end{array}$ \\
\hline 3 & $\begin{array}{l}\text { "My endocrinologist encourages me to see the educators as much as possible. His attitude and it's my attitude too, is that } \\
\text { educators are more on the lifestyle and he looks at the numbers. He does the medical side of things and whenever it is a } \\
\text { lifestyle issue, he deflects the question back to the educator. I'm actually comfortable with that; I think it is a good thing." } \\
\text { (Male patient aged } 32 \text { years, TIDM duration } 9 \text { years) }\end{array}$ \\
\hline 4 & $\begin{array}{l}\text { "From my perspective, at the end of the day the endocrinologist wants you to get your } \mathrm{Hb}_{\mathrm{Ic}} \text { as good as possible so you } \\
\text { don't get complications. I like that. I do have more time to talk with my educator about my diet and things. But knowing the } \\
\text { fact that the endocrinologist just focuses on your health: to make sure that you don't have high } \mathrm{HbA}_{\mathrm{Ic}} \mathrm{s} \text {, I find that a secure } \\
\text { and safe thing." (Female patient aged } 23 \text { years, TIDM duration II years) }\end{array}$ \\
\hline 5 & $\begin{array}{l}\text { "I guess he is very clinical and very results focused and you are out of there in } 10 \text { minutes." (Female patient aged } 32 \text { years, } \\
\text { TIDM duration } 25 \text { years) }\end{array}$ \\
\hline 6 & $\begin{array}{l}\text { "I only see my endocrinologist every twelve months. He doesn't ask me to talk for very long. It's a quick thing based on all } \\
\text { the numbers, so we don't have a lot of time to sit and chat." (Female patient aged } 31 \text { years, TIDM } 21 \text { years) }\end{array}$ \\
\hline 7 & $\begin{array}{l}\text { "If you're not careful you can lose your independence and become disempowered very easily. The medical profession can } \\
\text { have quite a negative impact on your life." (Female patient aged } 32 \text { years, TIDM duration } 25 \text { years) }\end{array}$ \\
\hline 8 & $\begin{array}{l}\text { "They said you have to check with your endocrinologist about changing your insulin levels. I'm the one who makes the } \\
\text { decisions. I feel I am quite autonomous. But they still wanted me to do so because they said it was protocol." (Female } \\
\text { patient aged } 27 \text { years, TIDM duration } 16 \text { years) }\end{array}$ \\
\hline 9 & $\begin{array}{l}\text { "I have a discussion. It's a bit more of an open table. I don't pay someone to tell me what l'm doing wrong ... I wouldn't go if } \\
\text { that were the case." (Male patient aged } 25 \text { years, TIDM duration } 6 \text { years) }\end{array}$ \\
\hline 10 & $\begin{array}{l}\text { "I recently changed endocrinologists, because (the previous endocrinologist) was very blasé. I'd only be there for about five } \\
\text { minutes; ten minutes maximum. I had got used to it. But my boyfriend came with me once and he said that I needed someone } \\
\text { who talked with me more about what I was doing. (The new endocrinologist) is really good. I was with him for an hour. We } \\
\text { really went through a lot and I was very happy. So a big change!" (Female patient aged } 27 \text { years, TIDM duration I6 years) }\end{array}$ \\
\hline
\end{tabular}

Whether the clinician listened to the patient's opinion about self-management

II "I don't know if he's a good or a bad endocrinologist compared to anyone else but he seems good because he'll listen to me." (Male patient aged 25 years, TIDM duration 6 years)

12

"From what I have experienced so far I have not had any one fantastic yet. The (endocrinologist) that I have at the moment, it is like talking to a cardboard box: there is nothing there. She has the knowledge but she won't listen." (Female patient aged 33 years, TIDM duration 13 years)

"I did see (an endocrinologist) but she wasn't someone you could talk to. So I haven't seen anyone since." (Female patient aged 30 years, TIDM 12 years)

"I think my body was reacting differently to what she suggested ... It's just those sorts of things where she obviously was just saying what her medical wad of documentation told her. Textbook stuff!" (Female patient aged 23 years, TIDM duration 13 years)

"The diabetes educator, it is like they have been told these rules that they seem to pass on. ... It is like they think it is really simple. ... For example she said if you're hypo you need to eat two exchanges of low Gl stuff after you've eaten an exchange of this. And I said: 'No I don't; then I'm going to be too high.' It is always the textbook answer that is given." (Male patient aged 28 years, TIDM duration 3 years) give it a go for a few days and I change the insulin. But then I just get high sugars and I get annoyed so I just change it back again." (Female patient aged 33 years, TIDM duration 13 years) slightly and then just kept getting hypos until I dramatically reduced it. So those sorts of things where she obviously was applying her medical documentation rather than listening to me." (Female patient aged 23 years, TIDM duration I 3 years) "Then they told me to split my Lantus but I didn't want to add another needle to my day so I just adjusted all my insulins myself by trial and error." (Female patient aged 21 years, TIDM duration 17 years) a really bad hypo one day because I injected what he told me to but it was more than I needed for the physical work I was doing. It hit me pretty quickly that I had to be responsible for managing this. I could not rely on the endocrinologists and nurses because only I could work out how much exercise was involved in that day's work." (Male patient aged 25 years, TIDM duration 6 years) 
experiences and that failure to listen was a reason to terminate a therapeutic relationship (Table 5, quotes 11, 12, and 13). Participants cited examples of clinician recommendations for diabetes management regimens based on theoretical expertise that did not account for the implementation constraints that participants had experienced.

Consultations where clinicians failed to listen to the participants' experiences were often characterized by reliance on theoretical knowledge ("textbook stuff") rather than engaging with the real-world problems for which the participants were seeking help (Table 5, quotes 14 and 15). Similarly, some clinicians failed to listen to the needs and preferences of their patients. This resulted in the clinician recommending ineffective or unsuitable treatment regimens (Table 5, quotes 16 and 17) or regimens that were later abandoned by participants (Table 5, quotes 18 and 19).

\section{Whether clinicians' behavior was supportive and encouraged patient autonomy}

Participants described clinicians who were supportive of SDM as having the following attributes (Table 6): taking a personal interest in the patient (Table 6, quotes 20 and 21); not trivializing patient concerns (Table 6, quotes 22 and 23); enquiring about patient-led self-management; listening to the patient and providing treatment options (Table 6, quotes 24 and 25); suggesting small achievable steps in management change (Table 6, quote 26); providing flexible access to clinician advice by phone or email (Table 6, quotes 27 and 28); and providing affirmation of the outcomes achieved by the patient (Table 6, quotes 29 and 30).

Typically, supportive consultations involved an acknowledgement by the clinician of the inherent necessity to adapt any advice offered by them to real-world scenarios. To assist with this need, such clinicians often provided access by email or phone for further advice if implementation of the agreed management plan proved difficult. Participants reported that this consultation style provided both support and affirmation of their capacity to cope with the daily demands of maintaining target levels of disease management.

Participants stated that when consultations were not characterized by SDM, they were left feeling disempowered and blamed for failure to reach treatment target levels (Table 6, quotes 31 and 32). Such consultations involved a failure by clinicians to demonstrate empathy (Table 6, quotes 33 and 34 ), or criticism of participants' lifestyle choices without offering constructive alternatives (Table 6, quotes 35 and 36). Participants reported that some clinicians had "scriptlike consultation routines" that discouraged any involvement in SDM. Many participants had decided to terminate consultation altogether with various clinicians or groups of clinicians because of repeated experiences of failure of these clinicians to orient toward SDM (Table 6, quotes 37, 38, and 39).

\section{Whether clinicians provided advice that patients could utilize to improve self-management}

Thematic analysis revealed three categories of factors impacting on clinician behavior regarding provision of advice that the patient could utilize to improve self-management (Table 7). These three factors related to the capacity of the participant to be able to trust the clinician's advice, the consistency of advice provided across the health care team, and whether the clinician suggested new technologies for self-management.

\section{Capacity of the participant to be able to trust the clinician's advice}

Participants reported that a fundamental basis for SDM was an ability to be able to depend on the integrity of clinician advice. Trust in the quality of the information exchanged in a consultation was vital for development of a therapeutic relationship (Table 7, quotes 40 and 41). Participants identified that the imperative for accurate information was more important than for the immediacy of information, and a delayed response provided participants with reassurance that the clinician was attempting to obtain the best available information. Such information exchange often involved use of email postconsultation (Table 7, quotes 42 and 43). Participants reported a preference for clinicians who were aware of current research and evidence-based practice (Table 7, quotes 44 and 45). Participants identified a lack of trust in clinician advice as a reason to discontinue further consultation with that clinician (Table 7, quotes 46 and 47).

\section{Consistency of advice provided across the health care team}

Participants identified that a barrier to SDM occurred when inconsistent advice was provided across the health care team. The occurrence of these situations was heightened when participants were exposed to a rotation of unfamiliar hospitalbased clinicians in outpatient clinics (Table 7, quote 48). Not only was the capacity to engage in SDM compromised, but provision of inconsistent advice added to the burden of living with a chronic illness (Table 7, quotes 49 and 50). However, some participants reported that provision of multiple or conflicting clinician opinions had inherent benefits because it exposed the participant to greater options (Table 7, quotes 51 and 52) and because clinician opinion was not consistent it encouraged greater patient autonomy (Table 7, quotes 53 and 
Table 6 Participant quotations about whether clinicians' behavior was supportive and encouraged patients' autonomy

\begin{tabular}{|c|c|}
\hline Quotation number & Quotation \\
\hline \multicolumn{2}{|c|}{ Supportive clinician behavior } \\
\hline 20 & $\begin{array}{l}\text { "(Diabetes clinic) is supportive as they treat you as a friend as soon as you go in there. That was a big thing for me." } \\
\text { (Female patient aged } 24 \text { years, TIDM duration } 2 \text { years) }\end{array}$ \\
\hline 21 & $\begin{array}{l}\text { "My endocrinologist, I found him myself. I needed to be able to relate to my doctor. I have developed a personal relationship with } \\
\text { him. I would probably enjoy hanging out with him, outside of the office." (Male patient aged } 22 \text { years, TIDM duration I6 years) }\end{array}$ \\
\hline 22 & $\begin{array}{l}\text { "Because I can call them up at any time and ask questions and anything that I ask they do not make me feel stupid." } \\
\text { (Female patient aged } 20 \text { years, TIDM } 3 \text { years) }\end{array}$ \\
\hline 23 & $\begin{array}{l}\text { "When I express my worries she is very supportive, very understanding, always available, very compassionate, } \\
\text { and genuinely sincere." (Female patient aged } 32 \text { years, TIDM duration } 2 \text { years) }\end{array}$ \\
\hline 24 & $\begin{array}{l}\text { "I see (...) and she absolutely doesn't tell me what I should be doing but gives options." (Female patient aged } 27 \text { years, } \\
\text { TIDM } 16 \text { years) }\end{array}$ \\
\hline 25 & $\begin{array}{l}\text { "My endocrinologist is really good. She gives me heaps of options and she'll ring me and I can ring her." (Female patient aged } \\
32 \text { years, TIDM duration } 25 \text { years) }\end{array}$ \\
\hline 26 & $\begin{array}{l}\text { "Instead of telling them they were idiots and should wake up to themselves she was like: "What is the first small step you can } \\
\text { take to better management?"' (Female patient aged } 27 \text { years, TIDM duration } 16 \text { years) }\end{array}$ \\
\hline 27 & $\begin{array}{l}\text { "My endocrinologist ... if she thinks a course of action is a good thing, she'll tell me about it and then say basically ... } \\
\text { 'Are you going to be able to give it a go? Email me when you're having any issues.' Things like that I find incredibly helpful." } \\
\text { (Female patient aged } 33 \text { years, TIDM duration } 25 \text { years) }\end{array}$ \\
\hline \multirow{3}{*}{$\begin{array}{l}29 \\
30\end{array}$} & $\begin{array}{l}\text { "She spent ages on the phone with me ... having the capacity to call someone or email them directly is such a relief and I feel } \\
\text { good about that." (Female patient aged } 33 \text { years, TIDM duration } 6 \text { years) }\end{array}$ \\
\hline & "She knows that I work hard at trying to control my diabetes." (Female patient aged 27 years, TIDM duration 16 years) \\
\hline & $\begin{array}{l}\text { "When I do things, which she thinks is a positive step, I get lots of affirmations." (Female patient aged } 32 \text { years, } \\
\text { TIDM duration } 25 \text { years) }\end{array}$ \\
\hline \multicolumn{2}{|c|}{ Unsupportive clinician behavior } \\
\hline 31 & $\begin{array}{l}\text { "I had to very quickly learn to state my case. I found that if I was feeling ... blamed for high sugar levels when l'd done } \\
\text { everything right, it was like, I don't want to see you anymore because I need someone who's going to help me manage this for } \\
\text { the rest of my life. That was something I decided quite early on." (Female patient aged } 33 \text { years, TIDM duration } 25 \text { years) }\end{array}$ \\
\hline 32 & $\begin{array}{l}\text { "I recently made a decision not to see an endocrinologist anymore unless I have to. I go and see an educator because } \\
\text { instead of making me feel like everything's just numbers and I'm being judged on everything, she gives me another side to it." } \\
\text { (Female patient aged } 2 \text { I years, TIDM duration } 17 \text { years) }\end{array}$ \\
\hline 33 & $\begin{array}{l}\text { "It is really helpful having a person understand my emotions and how I feel ... but the educators and endocrinologists are } \\
\text { quite removed from it all." (Female patient aged } 3 \text { I years, TIDM duration } 2 \mathrm{I} \text { years) }\end{array}$ \\
\hline 34 & $\begin{array}{l}\text { "The endocrinologist that I have at the moment, it's like talking to a cardboard box ... She does not have feelings for what } \\
\text { you're going through." (Female patient aged } 33 \text { years, TIDM duration I } 3 \text { years) }\end{array}$ \\
\hline 35 & $\begin{array}{l}\text { "In the hands of the specialist who said lose weight, get your sugar levels down; I did not know what to do. I was already not } \\
\text { eating in an attempt to do that." (Female patient aged } 33 \text { years, TIDM duration } 25 \text { years) }\end{array}$ \\
\hline 36 & $\begin{array}{l}\text { "I can't even make an appointment to see a dietician because of too many years of being told you should not be eating that ... } \\
\text { I'm sick of being told what not to do. I need to know what I can do." (Female patient aged } 33 \text { years, TIDM duration } 25 \text { years) }\end{array}$ \\
\hline 37 & $\begin{array}{l}\text { "It's too much academic. Not enough reality or world experience or listening to diabetics instead of telling them." } \\
\text { (Male patient aged } 25 \text { years, TIDM duration } 6 \text { years) }\end{array}$ \\
\hline 38 & $\begin{array}{l}\text { "I feel my visits to (the endocrinologist) are redundant because I know exactly how the conversation is going to go. I would } \\
\text { prefer to just pick up the phone and ask them what my HbA } \mathrm{I}_{\mathrm{Ic}} \text { is and then move on because quite often that is all I get out of } \\
\text { it." (Female patient aged } 27 \text { years, TIDM duration } 16 \text { years) }\end{array}$ \\
\hline 39 & $\begin{array}{l}\text { "I don't consult with a GP because I would go in and know exactly the questions they would ask because it is like they have } \\
\text { a script: What sort of insulin are you on, how many times a day do you take the insulin, how are your feet?" (Female patient } \\
\text { aged } 32 \text { years, TIDM duration } 25 \text { years) }\end{array}$ \\
\hline
\end{tabular}

Abbreviations: GP, general practitioner; TIDM, type I diabetes mellitus.

54). However, for other participants, the burden of dealing with the inconsistency of advice between clinicians acted as a driver to discontinue further consultation with clinicians (Table 7, quotes 55 and 56).

\section{Whether the clinician suggested new technologies for self-management}

Participants reported a tendency for some clinicians to fail to recommend new technologies to assist with self-management. This led to participant-driven instigation of discussion with clinicians about whether to introduce the use of new technologies into the management regimen. Some participants perceived that certain providers were not familiar with, or were resistant to, use of new technologies (Table 7, quotes 57 and 58). Participants identified a perceived lack of clinician familiarity with these new technologies as a barrier to SDM (Table 7, quotes 59 and 60). 
Table 7 Participant quotations about whether clinicians provided advice that patients could utilize to improve self-management

\begin{tabular}{|c|c|}
\hline Quotation number & Quotation \\
\hline \multicolumn{2}{|c|}{ Capacity of the participant to be able to trust the clinician's advice } \\
\hline 40 & $\begin{array}{l}\text { He bluffs a bit ... So I didn't have any faith in him ... I will go and see someone new ... I want to build a relationship with } \\
\text { someone." (Female patient aged } 28 \text { years, TIDM duration } 2 \text { years) }\end{array}$ \\
\hline 41 & $\begin{array}{l}\text { "Sometimes when you ask doctors for information you feel they start fudging information. I feel that they start to fudge } \\
\text { answers because at times I feel that they may not know the exact details. ... But she (the endocrinologist) was amazing in } \\
\text { terms of giving full answers. ... When I would ask questions she would give me really simple to understand information." } \\
\text { (Female patient aged } 32 \text { years, TIDM duration } 25 \text { years) }\end{array}$ \\
\hline 42 & $\begin{array}{l}\text { "Anything l've asked her she's been able to answer and if she doesn't know straight away she'll either give me a call or send } \\
\text { me an email with the answer." (Female patient aged } 26 \text { years, TIDM duration } 2 \text { years) }\end{array}$ \\
\hline 43 & $\begin{array}{l}\text { "I have a good GP. She does not pretend to know everything about diabetes. So she has baseline knowledge and if she can't } \\
\text { answer my question she will refer me to someone who can answer it." (Female patient aged } 33 \text { years, TIDM } 6 \text { years) }\end{array}$ \\
\hline 44 & $\begin{array}{l}\text { "They have to keep up to date with all the clinical data and all the overseas trials. He goes to overseas conferences and that } \\
\text { kind of reassures me a bit more." (Female patient aged } 24 \text { years, TIDM II years) }\end{array}$ \\
\hline 45 & $\begin{array}{l}\text { "She was fantastic because she kept up with the latest research and I found that very supportive." } \\
\text { (Female patient aged } 30 \text { years, TIDM duration } 12 \text { years) }\end{array}$ \\
\hline 46 & $\begin{array}{l}\text { "Diabetes educators I'm not a big fan of. I don't think they know much ... I haven't had any good experience with them so } \\
\text { far... So I do not consult with them." (Female patient aged } 33 \text { years, TIDM duration I } 3 \text { years) }\end{array}$ \\
\hline 47 & "I don't consult with a GP. Their knowledge is lacking about type I diabetes." (Female patient aged 28, TIDM duration 2 years) \\
\hline \multicolumn{2}{|c|}{ Consistency of advice provided across the health care team } \\
\hline 48 & $\begin{array}{l}\text { "It's frustrating because you go to the educator and they will tell you one thing, and then you go to the endocrinologist and } \\
\text { they will tell you something else ... Because it is a different doctor every time, then I always take what the doctor says with a } \\
\text { pinch of salt." (Female patient aged } 24 \text { years, TIDM duration } 2 \text { years) }\end{array}$ \\
\hline 49 & $\begin{array}{l}\text { "I think it adds to the emotional drain of diabetes because every doctor has such a different approach." (Female patient aged } \\
24 \text { years, TIDM duration } 18 \text { years) }\end{array}$ \\
\hline 50 & $\begin{array}{l}\text { "It is emotionally draining having to explain the way you approach your diabetes every time." (Female patient aged } 33 \text { years, } \\
\text { TIDM duration } 25 \text { years) }\end{array}$ \\
\hline 51 & $\begin{array}{l}\text { "I have to swap between three different endocrinologists. It is OK, everybody has a different opinion and some bits work } \\
\text { for you and some bits don't. If you know what you want to get out of it, it is good to see a few different ones." } \\
\text { (Female patient aged } 21 \text { years, TIDM duration } 17 \text { years) }\end{array}$ \\
\hline 52 & $\begin{array}{l}\text { "I've seen that many endocrinologists over the years that you learn to adapt. Some of them are better at certain things like } \\
\text { for example adjusting the pump." (Female patient aged } 3 \text { I years, TIDM duration } 20 \text { years) }\end{array}$ \\
\hline 53 & $\begin{array}{l}\text { "I definitely get mixed messages. ... She thinks that and he thinks that and I take it all in and go well what do I think and what } \\
\text { would work for me and I trial and error all of them." (Female patient aged } 24 \text { years, TIDM duration } 2 \text { years) }\end{array}$ \\
\hline 54 & $\begin{array}{l}\text { "At the end of the day you are the expert ... If you can't figure it out it is good to get advice from the specialists. But even } \\
\text { when they offer you the advice, it is like yeah NO!" (Female patient aged } 28 \text { years, TIDM duration } 2 \text { years) }\end{array}$ \\
\hline 55 & $\begin{array}{l}\text { "I don't even tend to ask them anymore. I just either do it myself or look it up online." (Female patient aged } 25 \text { years, } \\
\text { TIDM duration } 3 \text { years) }\end{array}$ \\
\hline 56 & $\begin{array}{l}\text { "I think it is probably more the educator that the other people to say the right things. Which is why I stopped seeing an } \\
\text { endocrinologist and a dietician too." (Female patient aged } 23 \text { years, duration TIDM duration I } 3 \text { years) }\end{array}$ \\
\hline \multicolumn{2}{|c|}{ Whether clinician suggested new technologies for self-management } \\
\hline 57 & “My endocrinologist never even mentioned the pump to me." (Female patient aged 24 years, TIDM duration II years) \\
\hline 58 & $\begin{array}{l}\text { "I asked to go on CGM but I was rejected. (The endocrinologist) just said No! He didn't even look into it!” (Male patient } \\
\text { aged } 22 \text { years, TIDM duration } 16 \text { years) }\end{array}$ \\
\hline 59 & $\begin{array}{l}\text { "I got a bit annoyed because my endocrinologist has never suggested this. It's purely because she's like, 'Well you've got } \\
\text { good control. Like why would you?' They don't think to." (Female patient aged } 28 \text { years, TIDM duration } 2 \text { years) }\end{array}$ \\
\hline 60 & $\begin{array}{l}\text { "I feel like I need to pull information out of her. If I did not think up the questions about you know splitting my insulin dose } \\
\text { or doing various other things then she wouldn't offer the assistance." (Female patient aged } 27 \text { years, TIDM duration } \\
\text { I6 years) }\end{array}$ \\
\hline
\end{tabular}

Abbreviations: CGM, continuous glucose monitoring; GP, general practitioner; TIDM, type I diabetes mellitus.

\section{Discussion}

Overall, we found that a high proportion of survey participants expressed some level of agreement that they had experienced facets of SDM being implemented in their clinician encounters. The results were consistent across all clinician groups in the multidisciplinary diabetes team studied. The wide spread of locations of our respondents, which is consistent with the population distribution across Australia, reduced the risk that a small number of clinicians who actively engaged in SDM in each clinician group had 
unduly influenced the overall results. We found that our participants in the focus groups preferred clinicians who engaged in SDM. The focus groups revealed that participant perception of a failure by clinicians to engage in SDM was a common reason cited for discontinuing consultation with that clinician or group of clinicians.

The focus group discussion indicated that SDM is best implemented when there is clinician respect for patient expertise in re-evaluating the management plan and there is ready accessibility to clinician advice outside of face-to-face consultation time, which is consistent with the work of Mol. ${ }^{43}$ Mol proposes that SDM should not be seen as a series of static decisions made by the patient and clinician at a particular time, but as a process that requires never-ending adaptability to the "messy reality of life". Legare and Witteman recognize the need for adaptive tools to support such a flexible model of SDM. ${ }^{2}$

Our participants' reports that clinician engagement in SDM is affected by the time pressure of clinician workloads has been noted in other studies. ${ }^{44}$ However, there is no evidence to support the premise that SDM is more timeconsuming than other models of care. ${ }^{2}$ A division in the types of responsibility for SDM amongst different members of the health care team, as observed by some of our participants, has been suggested as a method to improve more widespread facilitation of SDM. ${ }^{3}$

Our finding that the advice provided was sometimes inconsistent across the multidisciplinary groups suggests that clinicians need to better case manage their diabetes patients. Our study provides impetus for better coordination of multidisciplinary care. However our findings provide evidence that among the multidisciplinary clinicians consulted, SDM was being practiced, and that this ideological shift in health service delivery is emerging in clinical practice. Our findings are consistent with a recent comparative international study by the Commonwealth Fund that examined SDM in patients with complex chronic illness and found that patients in Switzerland, the UK, Australia, New Zealand, and the USA were the most likely to report facets of shared decisionmaking, with strong majorities (65\%-73\%) saying that their clinicians always or often spent enough time with them, encouraged questions, and provided clear explanations. ${ }^{45}$

Recruitment of the study sample by self-selection and through advertisements in diabetes-related support organizations introduced a potential for bias into this study. Eighty percent of the survey sample was female. The Australian National Diabetes Register records incidence rates for children younger than 15 years as approximately equal for males and females. However, for the age groups 15-19 years, 20-24 years, 25-29 years, and 30-34 years, males slightly exceed females, thus skewing our bias further towards females. Eighty-four percent of participants had private health insurance and $79 \%$ had tertiary or higher levels of education. These are higher than national averages. Further, $34 \%$ of the sample reported that their last $\mathrm{HbA}_{1 \mathrm{c}}$ was less than $7 \%$, whereas it has been reported that less than $20 \%$ of adults with diabetes in Australia maintain an $\mathrm{HbA}_{1 \mathrm{c}}$ level $<7 \%{ }^{46,47}$ Further, our attrition rate from all services was $2 \%$, whereas attrition rates in Australia have been reported in this age group as high as $50 \% .^{38}$ The demographic and clinical characteristics of our sample, particularly in relation to their level of education, might indicate that bias would be more towards patients who actively sought SDM. People with less education and those with fewer numeracy skills report decreased levels of engagement with SDM. ${ }^{48}$ The survey data may overemphasize the uptake of SDM by diabetes educators, dieticians, and general practitioners due to the smaller numbers of participants in our study consulting those clinicians. Further, the clinical indicators recorded in our survey were self-reported and therefore the results may be subject to recall and reporting bias. Due to the specific age range of our participants, our results may not be generalizable across all type 1 diabetes health services.

Qualitative studies such as this one collect large amounts of data from a small number of informants or study sites. They are not designed to estimate proportions in a wider population, quantify relationships between predetermined variables, or provide a single representative or average view or opinion. Instead, they seek to document and explain the variation in a wide range of views, needs, values, practices, and beliefs.

\section{Conclusion}

Assisting type 1 diabetes self-management practices through shared decision-making and empowering patients by promoting patient autonomy can be instrumental in avoiding diabetes-related disease complications and improving glycemic control. ${ }^{22}$ Our findings indicate that although some clinicians are embracing SDM, the reported experiences of young adults with type 1 diabetes indicate there are opportunities to improve clinician engagement in SDM across all groups of the multidisciplinary diabetes team.

The results suggest that such improvements could lead to increased patient uptake of diabetes-related health services by retaining patients who are currently rejecting certain clinician services due to the failure of those clinicians to practice SDM. 
The high attrition rate of young adults from diabetes health services, ${ }^{37,38}$ and the poor health outcomes faced by this group, ${ }^{46,47}$ act as strong imperatives to ensure that diabetes health services are more patient-centered. This study provides insights into ways that may assist in improving health service delivery and health outcomes for these young adults.

\section{Author contributions}

JW researched data, contributed to the conception, design and discussion of the research, wrote, reviewed, and edited the manuscript. MW researched data, contributed to discussion, reviewed and edited the manuscript. JG, RD, and JB contributed to the conception design and discussion of the research, and reviewed and edited the manuscript. All authors guarantee this work and are accountable for all aspects of this work.

\section{Acknowledgments}

This research was conducted under the auspices of a program of research funded by the National Health and Medical Research Council (NHMRC) of Australia: NHMRC Program Grant 568612. The failure of the majority of Australian adults to reach clinically dictated treatment target levels of Type 1 diabetes control is a case study in the program. We thank the young adults that were involved in the focus groups and/or the survey for their contribution to this research. We acknowledge Janet Long's contribution to data analysis and discussion and the editorial contribution of Dr Wendy Lipworth, Professor Don Chisholm AO, and Professor Lesley Campbell AM. A version of this paper was presented at the International Society for Quality in Health Care, 29th International Conference. Geneva, Switzerland. 21-24 October 2012.

\section{Disclosure}

The authors declare that they have no competing interests in this work.

\section{References}

1. Charles C, Gafni A, Whelan T. Shared decision-making in the medical encounter: what does it mean? (or it takes at least two to tango). Soc Sci Med. 1997;44(5):681-692.

2. Legare F, Witteman HO. Shared decision making: examining key elements and barriers to adoption into routine clinical practice. Health Aff (Millwood). 2013;32(2):276-284.

3. Friedberg MW, Van Busum K, Wexler R, Bowen M, Schneider EC. A demonstration of shared decision making in primary care highlights barriers to adoption and potential remedies. Health Aff (Millwood). 2013;32(2):268-275.

4. Barry MJ, Edgman-Levitan S. Shared decision making - pinnacle of patient-centered care. N Engl J Med. 2012;366(9):780-781.
5. Australian Commission on Safety and Quality in Health Care. PatientCentred Care: Improving Quality and Safety through Partnerships with Patients and Consumers. Sydney, Australia: Australian Commission on Safety and Quality in Health Care; 2011.

6. Gerteis M, Edgman-Levitan S, Daley J, DelBanco TL. Through the Patient's Eyes: Understanding and Promoting Patient-Centred Care. San Francisco, CA, USA: Jossey-Bass; 1993.

7. Schaller D. Patient-Centered Care: What Does It Take? Picker Insitute and Commonwealth Fund; 2007. Available from: http://www. commonwealthfund.org/Publications/Fund-Reports/2007/Oct/PatientCentered-Care-What-Does-It-Take.aspx. Accessed December 17, 2013.

8. Robb G, Seddon M; Effective Practice Informatics and Quality (EPIQ). Quality improvement in New Zealand healthcare. Part 6: keeping the patient front and centre to improve healthcare quality. $N Z \mathrm{Med} J$. 2006;119(1242):U2174.

9. Moulton B, King JS. Aligning ethics with medical decision-making: the quest for informed patient choice. J Law Med Ethics. 2010;38(1): 85-97.

10. Harter M, Muller H, Dirmaier J, Donner-Banzhoff N, Bieber C, Eich W. Patient participation and shared decision making in Germanyhistory, agents and current transfer to practice. Z Evid Fortbild Qual Gesundhwes. 2011;105(4):263-270.

11. Moumjid N, Christine D-B, Denois-Regnier V, Roux P, Soum-Pouyalet F. Shared decision making in the physician-patient encounter in France: a general overview in 2011. Z Evid Fortbild Qual Gesundhwes. 2011;105(4):259-262.

12. van der Weijden $T$, van Veenendaal H, Drenthen $T$, et al. Shared decision making in The Netherlands, is the time ripe for nationwide, structural implementation? Z Evid Fortbild Qual Gesundhwes. 2011;105(4):283-88.

13. Legare F, Stacey D, Forest P-G, Coutu M-F. Moving SDM forward in Canada: milestones, public involvement, and barriers that remain. Z Evid Fortbild Qual Gesundhwes. 2011;105(4):245-253.

14. Coulter A, Edwards A, Elwyn G, Thomson R. Implementing shared decision making in the UK. Z Evid Fortbild Qual Gesundhwes. 2011;105(4):300-304.

15. Stacey D, Bennett CL, Barry MJ, et al. Decision aids for people facing health treatment or screening decisions. Cochrane Database Syst Rev. 2011;10:CD001431.

16. Attale C, Lemogne C, Sola-Gazagnes A, et al. Therapeutic alliance and glycaemic control in type 1 diabetes: a pilot study. Diabetes Metab. 2010;36(6 Pt 1):499-502.

17. Cvengros JA, Christensen AJ, Cunningham C, Hillis SL, Kaboli PJ. Patient preference for and reports of provider behavior: impact of symmetry on patient outcomes. Health Psychol. 2009;28(6):660-667.

18. Kinmonth AL, Woodcock A, Griffin S, Spiegal N, Campbell MJ. Randomised controlled trial of patient centred care of diabetes in general practice: impact on current wellbeing and future disease risk. The Diabetes Care From Diagnosis Research Team. BMJ. 1998;317(7167):1202-1208.

19. Bauman A, Fardy H, Harris P. Getting it right: why bother with patientcentred care? Med J Aust. 2003;179(5):253-256.

20. Nolte E, McKee M. Caring for People with Chronic Conditions: A Health System Perspective. Berkshire, UK: World Health Organization; 2008.

21. Deci EL, Ryan RM. The "what" and "why" of goal pursuits: human needs and the self-determination of behavior. Psychol Inq. 2000;11(4):227-268.

22. Williams GC, McGregor HA, Zeldman A, Freedman ZR, Deci EL. Testing a self-determination theory process model for promoting glycemic control through diabetes self-management. Health Psychol. 2004;23(1):58-66.

23. Coulter A, Parsons S, Askham J. Where are the Patients in DecisionMaking about their Own Care. Copenhagen, Denmark: World Health Organization Regional Office for Europe; 2008. 
24. Salzburg Global Seminar. The Salzburg Statement on Shared DecisionMaking. 2011. Available from: http://us.cochrane.org/sites/us.cochrane. org/files/uploads/Ford,\%20Peg\%20-\%20Salzburg-Statementammended5.pdf. Accessed December 17, 2013.

25. Grol R, Wensing M, Mainz J, et al. Patients in Europe evaluate general practice care: an international comparison. Br J Gen Pract. 2000;50(460):882-887.

26. Bezold $\mathrm{C}$. The future of patient-centered care: scenarios, visions, and audacious goals. J Altern Complement Med. 2005;11 Suppl 1: S77-S84.

27. Koch S. Improving quality of life through eHealth - the patient perspective. Stud Health Technol Inform. 2012;180:25-29.

28. Robinson JH, Callister LC, Berry JA, Dearing KA. Patient-centered care and adherence: definitions and applications to improve outcomes. J Am Acad Nurse Pract. 2008;20(12):600-607.

29. Gilbertson HR, Brand-Miller JC, Thorburn AW, Evans S, Chondros P, Werther GA. The effect of flexible low glycemic index dietary advice versus measured carbohydrate exchange diets on glycemic control in children with type 1 diabetes. Diabetes Care. 2001;24(7): 1137-1143.

30. Parillo M, Annuzzi G, Rivellese AA, et al. Effects of meals with different glycaemic index on postprandial blood glucose response in patients with type 1 diabetes treated with continuous subcutaneous insulin infusion. Diabet Med. 2011;28(2):227-229.

31. Marsh K, Barclay A, Colagiuri S, Brand-Miller J. Glycemic index and glycemic load of carbohydrates in the diabetes diet. Curr Diab Rep. 2011;11(2):120-127.

32. Porcellati F, Bolli GB, Fanelli CG. Pharmacokinetics and pharmacodynamics of basal insulins. Diabetes Technol Ther. 2011;13 Suppl 1: S15-S24.

33. Heptulla RA, Rodriguez LM, Mason KJ, Haymond MW. Gastric emptying and postprandial glucose excursions in adolescents with type 1 diabetes. Pediatr Diabetes. 2008;9(6):561-566.

34. Liang WW. Seasonal changes in preprandial glucose, $\mathrm{A}_{1 \mathrm{c}}$, and blood pressure in diabetic patients. Diabetes Care. 2007;30(10):2501-2502.

35. Chiu KC, Chu A, Go VLW, Saad MF. Hypovitaminosis D is associated with insulin resistance and beta cell dysfunction. Am J Clin Nutr. 2004;79(5):820-825.

36. Joosten EA, DeFuentes-Merillas L, de Weert GH, Sensky T, van der Staak CP, de Jong CA. Systematic review of the effects of shared decision-making on patient satisfaction, treatment adherence and health status. Psychother Psychosom. 2008;77(4):219-226.

37. Peters A, Laffel L; American Diabetes Association Transitions Working Group. Diabetes care for emerging adults: recommendations for transition from pediatric to adult diabetes care systems: a position statement of the American Diabetes Association, with representation by the American College of Osteopathic Family Physicians, the American Academy of Pediatrics, the American Association of Clinical Endocrinologists, the American Osteopathic Association, the Centers for Disease Control and Prevention, Children with Diabetes, The Endocrine Society, the International Society for Pediatric and Adolescent Diabetes, Juvenile Diabetes Research Foundation International, the National Diabetes Education Program, and the Pediatric Endocrine Society (formerly Lawson Wilkins Pediatric Endocrine Society). Diabetes Care. 2011;34(11):2477-2485.
38. Perry L, Steinbeck KS, Dunbabin JS, Lowe JM. Lost in transition? Access to and uptake of adult health services and outcomes for young people with type 1 diabetes in regional New South Wales. Med JAust. 2010;193(8):444-449.

39. Goodrich J, Cornwell J. Seeing the person in the patient: the point of care review paper. London, UK; 2008. http://www.kingsfund.org. $\mathrm{uk} /$ sites/files/kf/Seeing-the-person-in-the-patient-The-Point-of-Carereview-paper-Goodrich-Cornwell-Kings-Fund-December-2008.pdf. Accessed December 17, 2013.

40. Ngo-Metzger Q, Telfair J, Sorkin DH, et al. Cultural competency and the culture of care: obtaining the patients' perspective. The Commonwealth Fund; 2006. Available from: http://www.commonwealthfund.org/ usr_doc/Ngo-Metzger_cultcompqualitycareobtainpatientperspect_ 963.pdf. Accessed December 17, 2013.

41. Morgan DL, Krueger RA. When to use focus groups and why. In: Morgan DL, editor. Successful Focus Groups: Advancing the State of the Art. Newbury Park, CA, USA: Sage Publications; 1993.

42. Creswell J. Research Design: Qualitative, Quantitative and Mixed Method Approaches. 3rd ed. Thousand Oaks, CA, USA: Sage Publications; 2009.

43. Mol A. The Logic of Care: Health and the Problem of Patient Choice. 1st ed. Oxford, UK: Routledge; 2008.

44. Legare F, Ratte S, Stacey D, Kryworuchko J, Gravel K, Graham I. Interventions for improving the adoption of shared decision-making by healthcare professionals. Cochrane Database Syst Rev. 2010;5: CD006732.

45. Schoen C, Osborn R, Squires D, Doty M, Pierson R, Applebaum S. New 2011 survey of patients with complex care needs in eleven countries finds that care is often poorly coordinated. Health Aff (Millwood) 2011;30(12):2437-2448.

46. Bryant W, Greenfield JR, Chisholm DJ, Campbell LV. Diabetes guidelines: easier to preach than to practise? Med J Aust. 2006;185(6): 305-309.

47. McIntyre DH. DAFNE (Dose Adjustment for Normal Eating): structured education in insulin replacement therapy for type 1 diabetes. Med J Aust. 2006;184(7):317.

48. Kiesler DJ, Auerbach SM. Optimal matches of patient preferences for information, decision-making and interpersonal behavior: evidence, models and interventions. Patient Educ Couns. 2006;61(3):319-341.
Patient Preference and Adherence

\section{Publish your work in this journal}

Patient Preference and Adherence is an international, peer-reviewed open access journal focusing on the growing importance of patient preference and adherence throughout the therapeutic continuum. Patient satisfaction, acceptability, quality of life, compliance, persistence and their role in developing new therapeutic modalities and compounds to

\section{Dovepress}

optimize clinical outcomes for existing disease states are major areas of interest. This journal has been accepted for indexing on PubMed Central. The manuscript management system is completely online and includes a very quick and fair peer-review system. Visit http://www.dovepress.com/ testimonials.php to read real quotes from published authors. 